\title{
Effect of Platelet-Rich Plasma and Mesenchymal Stem Cells as Two Biological Alternatives in Rotator Cuff In- jury Treatment: A Mini-Review
}

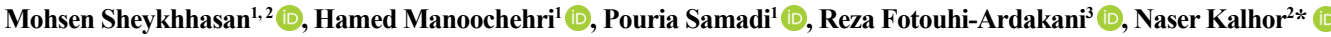 \\ 1. Research Center for Molecular Medicine, Hamadan University of Medical Sciences, Hamadan, Iran. \\ 2. Department of Mesenchymal Stem Cell, Academic Center for Education, Culture and Research, Qom Branch, Qom, Iran. \\ 3. Cellular and Molecular Research Center, Qom University of Medical Sciences, Qom, Iran.
}

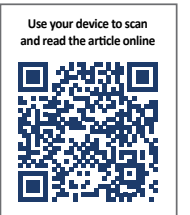

Citation Sheykhhasan M, Manoochehri H, Samadi P, Fotouhi-Ardakani R, Kalhor N. Effect of Platelet-Rich Plasma and Mesenchymal Stem Cells as Two Biological Alternatives in Rotator Cuff Injury Treatment: A Mini-Review. Research in Molecular Medicine. 2019; 7(3):1-8. https://doi.org/10.32598/rmm.7.3.1

https://doi.org/10.32598/rmm.7.3.1

\section{(c) (1) (s)}

Article Type:

Review Paper

Article info:

Received: 9 jun 2019

Revised: 30 jun 2019

Accepted: 24 Jul 2019

Keywords:

Platelet-rich plasma, Mesenchymal stem cells, Rotator cuff injury

\begin{abstract}
A B S T RA C T
The rotator cuff injury introduces as significant damage of trauma and others factors, and currently recognized as a prevalent orthopedic problem. Thus, many clinical procedures have been demonstrated to reduce the complication of rotator cuff injury with varying degrees of success. Platelet-Rich Plasma (PRP) is being enchantingly agreed as one of the most effectiveness strategies for the symptomatic treatment of rotator cuff injury. Many confusing parameters can influence the result of PRP including size of rotator cuff injury, patient age, PRP producing strategy, and number and timing of PRP injections. However, there is some evidences which support beneficial effect PRP in term relieving pain and restoring function, along with minimal adverse effect, in compared with corticosteroids, and other nonsurgical methods. Besides platelet-rich plasma, Mesenchymal Stem Cells (MSCs) are another biological alternative that can be used to treat rotator cuff injuries. Due to lack of large clinical trials applicability, these biological cells have challenges fairly similar to PRP. In conclusion, there is a need for further research to understand the potential application of both of these alternatives as a safe and effective therapeutic option for rotator cuff injuries.
\end{abstract}

\section{Introduction}

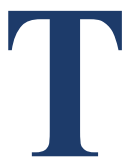

he rotator cuff consists of four muscles in addition to tendons that serve to fix the ball of the shoulder within the joint $[1,2]$. They also help to rotate the arms and assist in lifting $[1,2]$. Any damage to these muscles or tendons causes irreparable injury to the shoulder, which results in pain and inflammation $[1,2]$.
Rotator cuff problems, including rotator cuff tears, are one of the most prevalent orthopedic conditions (the occurrence probability is approximately $7 \%$ to $34 \%$ ), and that have increase its outbreak annually and the risk of sustaining such an injury rises with age [1-3].

While the common therapeutic modalities for rotator cuff tears include both surgical and nonsurgical management (e.g. exercise and rehabilitation), these methods are inefficient to treat this disease and can lead to unin-

\footnotetext{
* Corresponding Author:

Naser Kalhor, MSc.

Address: Department of Mesenchymal Stem Cell, the Academic Center for Education, Culture and Research, Qom Branch, Qom, Iran.

Phone: +98 (25) 32700155

E-mail: naserkalhor@gmail.com
} 

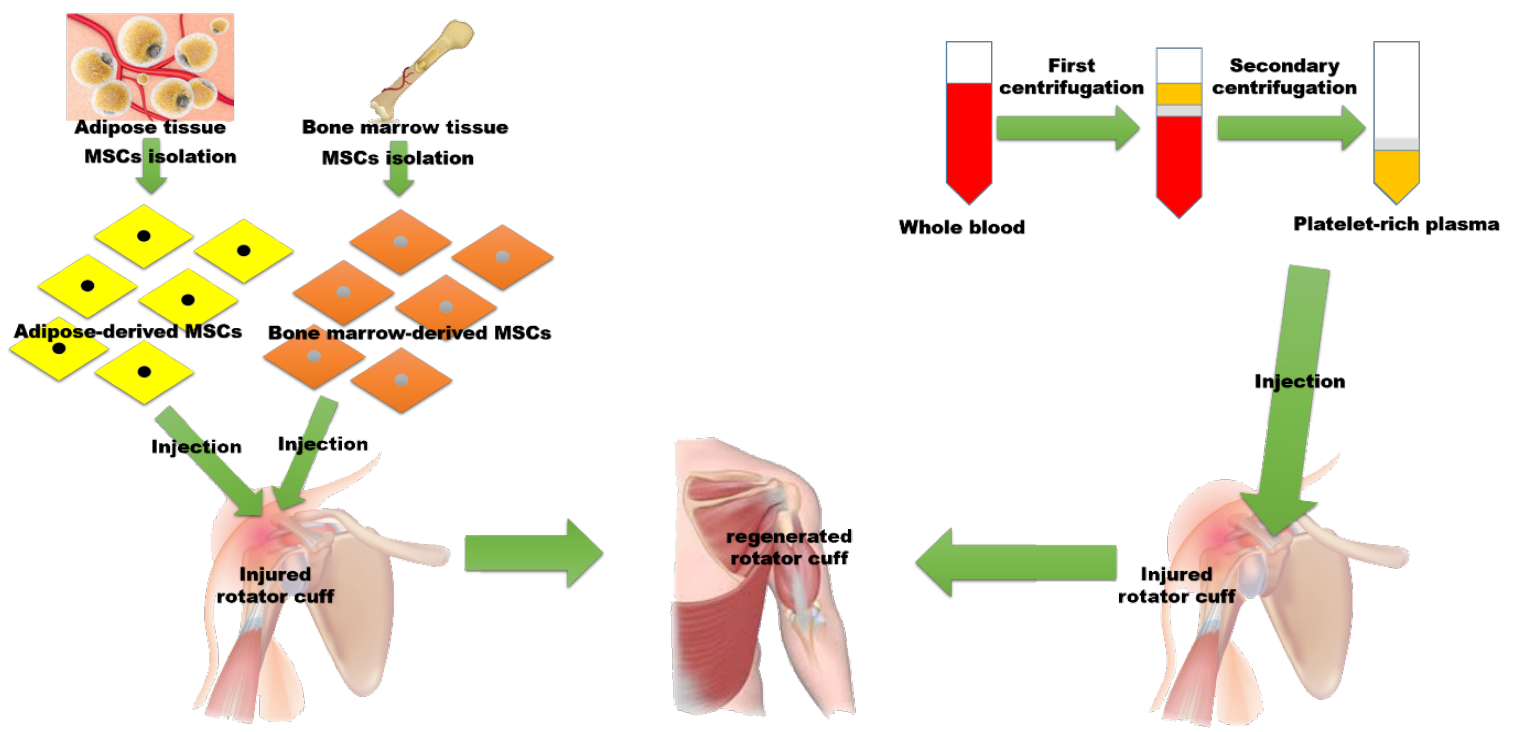

grmm

Figure 1. The importance of MSCs and PRP therapy for rotator cuff tears. The figure schematically demonstrates the ability of PRP and MSCs, especially AD- and BM-derived MSCs, in rotator cuff tear treatment.

tended consequences $[4,5]$. Furthermore, these methods do not have the ability to reverse the loss of structure and mobility in the shoulder [6]. Because of the challenges associated with conventional therapies, efforts to find more efficient and safe treatments for rotator cuff tears continue [7] Among these new treatments, biological methods, including Platelet-Rich Plasma (PRP) and Mesenchymal Stem Cells (MSCs), are considered both efficient and safe (Figure 1) [8].

\section{Use of platelet-rich plasma in rotator cuff in- jury treatment}

The results of numerous studies have shown that various growth factors and cytokines, including basic Fibroblast Growth Factor (bFGF), Vascular Endothelial Growth Factor (VEGF), Insulin-like Growth Factor 1 (IGF-1), Bone Morphogenetic Proteins (BMP), and Transforming Growth Factor- $\beta 3$ (TGF- $\beta 3$ ) may have a favorable effect on tear healing $[9,10]$.

PRP, a biological concentrate that contains a large amount of a number of growth factors, such as Transforming Growth Factor- $\beta 1$ (TGF- $\beta 1$ ), angiopoietin-1 (Ang-1), and Angiopoietin-2 (Ang-2), can be considered a therapeutic factor for the improvement of rotator cuff tear healing $[9,11-13]$.

Data obtained from in vivo studies appear to indicate that the application of PRP may have a therapeutic effect on rotator cuff tears [14]. Furthermore, some clinical trial studies also reported positive outcome of therapeutic usage of PRP in patients with rotator cuff tears in short-term [15-18]. So that, re-tear rate, pain, and shoulder function in patient were among the symptoms that were improved by using PRP in patients with rotator cuff tears [19]. Thus, PRP therapy is suggested as an auxiliary therapy in singlerow arthroscopic rotator cuff repair for ameliorated short period of time outcomes [19]. However, several clinical studies have reported contradictory findings in terms of the appropriateness of PRP for rotator cuff tears [20].

Several confounding factors could have led to these contradictions, including patient age, number and timing PRP injection, the different protocols and materials used in Randomized Clinical Trials (RCTs) to produce and processing the PRP, along with the various commercial methods that are available for this procedure, as well as a lack of homogeneity in studies and differences in the sizes of rotator cuff tears and the methods used for this damaged tissue repair [3].

For example, some studies have shown that PRP can play a role in reducing vascularity and cellularity and improving apoptosis in rotator cuff tears [21]. In addition, previous studies have demonstrated that PRP can considerably reduce re-tear rates in rotator cuff tears larger than $3 \mathrm{~cm}$ in anterior-posterior length by combination with a double-row technique [22].

One research study demonstrated that PRP was most successful at relieving pain and restoring function in symptomatic partial rotator cuff tears in comparison with other 
treatments, including corticosteroids [23]. However, most level I and II clinical studies have reported that platelet-rich plasma was not efficacious in terms of treating patients with rotator cuff tendinopathy compared to controls [3].

Thus, high-quality evidence and data associated with the therapeutic use of PRP for rotator cuff tear treatment is insufficient and remains limited, and small clinical trial just also demonstrates hopeful result of PRP use in rotator cuff tendinopathy cure; however, more clinical trials are needed to increase the number of findings and improve understanding of the function of PRP for the treatment of rotator cuff injury [24].

Some clinical studies using PRP for the treatment of rotator cuff injury are listed in Table 1 [15, 16, 25-33].

In addition, some protocols and materials used in PRP preparation for the treatment of rotator cuff injury are listed in Table $2[15,23,25,28,34,35]$.

\section{Use of mesenchymal stem cells in rotator cuff injury treatment}

Apart from PRP, Mesenchymal Stem Cells (MSCs) are another biological alternative that can be used to treat rotator cuff injuries too [36]. MSCs are one type of adult stem cells that are among the most widely used for discovering efficient approaches to cell therapies [37]. Currently, a growing body of evidence recommends that MSCs play a crucial role in comforting tissue regeneration by improving cell proliferation, differentiation, and growth processes, as well as inhibiting inflammation and Table 1. Some clinical studies using PRP for the treatment of rotator cuff injury

\begin{tabular}{|c|c|c|c|c|c|}
\hline Researchers & Clinical Trial Type & Number of Patients & Follow Up (Months) & Outcome & $\begin{array}{c}\text { Years/ } \\
\text { References }\end{array}$ \\
\hline $\begin{array}{l}\text { Roberto } \\
\text { Castricini } \\
\text { et al }\end{array}$ & $\begin{array}{l}\text { A Randomized Con- } \\
\text { trolled Trial }\end{array}$ & 48 & 16 & $\begin{array}{l}\text { There was no significant difference in } \\
\text { the treatment of rotator cuff injury }\end{array}$ & $\begin{array}{c}2011 \\
{[25]}\end{array}$ \\
\hline $\begin{array}{l}\text { Pietro Ran- } \\
\text { delli et al }\end{array}$ & $\begin{array}{l}\text { A prospective Random- } \\
\text { ized Controlled Trial } \\
\text { study }\end{array}$ & 53 & 24 & $\begin{array}{l}\text { There was no significant difference in } \\
\text { the treatment of rotator cuff injury }\end{array}$ & $\begin{array}{l}2011 \\
{[26]}\end{array}$ \\
\hline $\begin{array}{l}\text { Pietro S. } \\
\text { Randelli } \\
\text { et al }\end{array}$ & A pilot study & 14 & 24 & $\begin{array}{l}\text { There was a significant decrease in VAS } \\
\text { scores and significant increases in the } \\
\text { UCLA. }\end{array}$ & $\begin{array}{c}2008 \\
{[27]}\end{array}$ \\
\hline $\begin{array}{l}\text { Serdar } \\
\text { Kesikburun } \\
\text { et al }\end{array}$ & $\begin{array}{l}\text { A Randomized Con- } \\
\text { trolled Trial }\end{array}$ & 40 & 12 & $\begin{array}{l}\text { There was no significant difference in } \\
\text { the treatment of rotator cuff injury }\end{array}$ & $\begin{array}{l}2013 \\
{[28]}\end{array}$ \\
\hline $\begin{array}{l}\text { Dong-wook } \\
\text { Rha et al }\end{array}$ & $\begin{array}{l}\text { A Randomized Con- } \\
\text { trolled Trial }\end{array}$ & 39 & 6 & $\begin{array}{l}\text { There was no significant difference in } \\
\text { the treatment of rotator cuff injury. } \\
\text { No severe adverse effects were ob- } \\
\text { served in either group. }\end{array}$ & $\begin{array}{c}2012 \\
{[29]}\end{array}$ \\
\hline $\begin{array}{l}\text { Chris } \\
\text { Hyunchul Jo } \\
\text { et al }\end{array}$ & $\begin{array}{l}\text { A Prospective Cohort } \\
\text { Study }\end{array}$ & 42 & 16 & $\begin{array}{l}\text { There was no significant difference in } \\
\text { the treatment of rotator cuff injury }\end{array}$ & $\begin{array}{c}2011 \\
{[30]}\end{array}$ \\
\hline $\begin{array}{l}\text { Chris } \\
\text { Hyunchul Jo } \\
\text { et al }\end{array}$ & $\begin{array}{l}\text { A Randomized, Single- } \\
\text { Blind, Parallel-Group } \\
\text { Trial }\end{array}$ & 48 & 12 & $\begin{array}{l}\text { There was a significantly improved } \\
\text { structural outcomes, as evidenced by } \\
\text { a decreased retear rate and increased } \\
\text { CSA of the supraspinatus }\end{array}$ & $\begin{array}{c}2013 \\
{[31]}\end{array}$ \\
\hline $\begin{array}{l}\text { Chris } \\
\text { Hyunchul Jo } \\
\text { et al }\end{array}$ & $\begin{array}{l}\text { A Randomized Con- } \\
\text { trolled Trial }\end{array}$ & 74 & 12 & $\begin{array}{l}\text { There was a significant improved the } \\
\text { quality, as evidenced by a decreased } \\
\text { retear rate and increased CSA of the } \\
\text { supraspinatus. }\end{array}$ & $\begin{array}{l}2015 \\
{[32]}\end{array}$ \\
\hline $\begin{array}{l}\text { Ho-Won Lee } \\
\text { et al }\end{array}$ & $\begin{array}{l}\text { Prospective Clinical } \\
\text { Research }\end{array}$ & 60 & 6 & $\begin{array}{l}\text { PRP injection was more effective than } \\
\text { exercise therapy for the first } 3 \text { months. }\end{array}$ & $\begin{array}{c}2019 \\
{[33]}\end{array}$ \\
\hline $\begin{array}{l}\text { Yasmin } \\
\text { Khairy et al }\end{array}$ & $\begin{array}{l}\text { A Randomized Con- } \\
\text { trolled Trial }\end{array}$ & 60 & 3 & $\begin{array}{l}\text { There was improves patients' qual- } \\
\text { ity of life clinically, functionally and } \\
\text { structurally. }\end{array}$ & $\begin{array}{l}2019 \\
{[15]}\end{array}$ \\
\hline $\begin{array}{l}\text { Ruben Du- } \\
\text { kan et al }\end{array}$ & A prospective study & 69 & 24 & $\begin{array}{l}\text { There was significant difference in the } \\
\text { clinical and radiological results treat- } \\
\text { ment of rotator cuff injury at } 3 \text { months }\end{array}$ & $\begin{array}{l}2019 \\
{[16]}\end{array}$ \\
\hline $\begin{array}{l}\text { Doaa H. } \\
\text { Ibrahim } \\
\text { et al }\end{array}$ & $\begin{array}{l}\text { A Randomized Con- } \\
\text { trolled Trial }\end{array}$ & 30 & Approximately 2 & $\begin{array}{l}\text { There was a significant improvement in } \\
\text { the tear and effusion }\end{array}$ & $\begin{array}{c}2019 \\
{[34]}\end{array}$ \\
\hline
\end{tabular}


Table 2. Some protocols and materials used in PRP preparation for the treatment of rotator

\begin{tabular}{|c|c|c|c|c|c|c|}
\hline \multirow{2}{*}{ Study } & \multirow{2}{*}{$\begin{array}{l}\text { Volume of Whole } \\
\text { Blood (mL) }\end{array}$} & \multicolumn{4}{|c|}{ Force (rpm) / Time(Min) } & \multirow{2}{*}{ References } \\
\hline & & \multicolumn{2}{|c|}{ First Centrifugation } & \multicolumn{2}{|c|}{ Secondary Centrifugation } & \\
\hline Doaa H. Ibrahim et al & 20 & $700-1500$ & $15-20$ & 2500-3500 & 10 & [34] \\
\hline Yasmin Khairy et al & $\mathrm{nr}$ & 1000 & 10 & 3000 & 15 & [15] \\
\hline Serdar Kesikburun et al & 54 & 3200 & 15 & - & - & [28] \\
\hline Ahmed Shams et al & 10 & 3500 & 10 & - & - & [23] \\
\hline Andrew J. Carr et al & 50 & $\mathrm{nr}$ & $\mathrm{nr}$ & $\mathrm{nr}$ & $\mathrm{nr}$ & [35] \\
\hline Roberto Castricini et al & 9 & 1100 & 6 & $\begin{array}{l}4500 \text { relative centrifu- } \\
\text { gal force }[R C F]\end{array}$ & 5 & [25] \\
\hline Dong-wook Rha & 25 & $1600 \times g$ & $\mathrm{nr}$ & $2000 \times g$ & $\mathrm{nr}$ & [29] \\
\hline
\end{tabular}

Table 3. Some clinical studies using MSCs for the treatment of rotator cuff injury

\begin{tabular}{|c|c|c|c|c|c|}
\hline Researchers & Clinical Trial Type & Number of Patients & Follow up (Months) & Outcome & Years/References \\
\hline Brian J. Cole et al & $\begin{array}{l}\text { åA Prospective Ran- } \\
\text { domized Trial }\end{array}$ & 62 & 24 & $\begin{array}{c}\text { There was improved } \\
\text { tendon quality on } \\
\text { post-operative MRI at } \\
\text { 1-year }\end{array}$ & $\begin{array}{c}2019 \\
{[44]}\end{array}$ \\
\hline Philippe Hernigou et al & $\begin{array}{l}\text { A case-controlled } \\
\text { study }\end{array}$ & 45 & 24 & $\begin{array}{l}\text { There was a success- } \\
\text { ful repair during an } \\
\text { interval. }\end{array}$ & $\begin{array}{c}2014 \\
{[45]}\end{array}$ \\
\hline Philippe Hernigou et al & Not reported & 125 & Not reported & $\begin{array}{l}\text { There was no signifi- } \\
\text { cant difference in the } \\
\text { treatment of rotator } \\
\text { cuff injury. }\end{array}$ & $\begin{array}{c}2015 \\
{[46]}\end{array}$ \\
\hline Yong Sang Kim et al & $\begin{array}{l}\text { A Clinical and } \\
\text { Magnetic Resonance } \\
\text { Imaging Study }\end{array}$ & 182 & 28 & $\begin{array}{l}\text { There was significantly } \\
\text { improve structural } \\
\text { outcomes in terms of } \\
\text { the retear rate. } \\
\text { There were, however, } \\
\text { no clinical differences } \\
\text { in the } 28 \text {-month } \\
\text { period of follow-up. }\end{array}$ & $\begin{array}{c}2017 \\
{[43]}\end{array}$ \\
\hline V. Havlas et al & A Preliminary study & 10 & 6 & $\begin{array}{l}\text { using human cultured } \\
\text { autologous MSCs in } \\
\text { the treatment of rota- } \\
\text { tor cuff tears is safe }\end{array}$ & $\begin{array}{c}2015 \\
{[47]}\end{array}$ \\
\hline Sang Yoon Lee et al & A Pilot Study & 12 & 12 & $\begin{array}{l}\text { Allo-ASC therapy was } \\
\text { thus safe and effective } \\
\text { in improving elbow } \\
\text { pain, performance, } \\
\text { and structural defects } \\
\text { for } 52 \text { weeks. }\end{array}$ & $\begin{array}{c}2015 \\
{[48]}\end{array}$ \\
\hline
\end{tabular}

secreting a wide range of growth factors and cytokines associated with repair [37]. Furthermore, due to their immunomodulatory, immunogenicity, and fairly easy separation, MSCs are considered a therapeutic alternative for musculoskeletal conditions, such as rotator cuff injuries [38, 39].
As biological agents, bone marrow- and adipose-derived MSCs are two of the most important sources of MSCs for treating various conditions, including rotator cuff injuries [38]. These particular stem cells offer the benefit of a paracrine mechanism in addition to proliferation, differentiation, and anti-apoptotic activity [38-40]. 
Numerous preclinical studies and one clinical study have confirmed the positive effects of bone marrow- and adipose-derived MSCs on animal models and patients with rotator cuff injuries, respectively $[38,41]$.

Similar to PRP, however, bone marrow- and adiposederived MSCs are limited in terms of their use in a clinical setting [3, 42]. Therefore, there is a need for further research to understand the potential application of MSCs as a safe and effective therapeutic option for rotator cuff injuries. Although, an unpublished clinical trial performed on 18 patients with rotator cuff injuries reported that use of adipose-derived MSCs can contribute to the repair of partially torn rotator cuffs [43]. Furthermore, the adipose-derived MSCs treatment used in this study received safety approval from the Food and Drug Administration (FDA) for its use in rotator cuff injuries [43].

Recently, according to the results of a prospective randomized trial, the ability to use bone marrow-derived MSCs to improve patients undergoing arthroscopic rotator cuff repair has been confirmed [44]. In this study, it was demonstrated that injection of bone marrow-derived MSCs could supply a treatment strategy for 34 patients with a full-thickness supraspinatus tear or partial thickness converted to full thickness tear after one year's follow-up [44]. Some clinical studies using MSCs for the treatment of rotator cuff injury are listed in Table 3 [44-48].

In addition to mesenchymal stem cells, their exosomes can also be used as adjuncts to aid in shoulder regeneration because of their paracrine mechanism and regeneration ability [49]. For instance, Wang et al. (2019) reports that adipose-derived MSCs-Exosomes can significantly reduce degeneration and atrophy and ameliorate muscle repair and biomechanical characters in torn rotator cuff muscles [50]. Furthermore, Shi et al. (2019) demonstrate that the local injection of bone marrow-derived MSCs-Exosomes stimulate tendon regeneration by inhibiting apoptosis and inflammation mechanism and improving the proportion of tendon-resident stem/progenitor cells [51]. These results supply a basis for the potential clinical administration of exosomes derived MSCs in tendon healing.

\section{Conclusion and Future Perspective}

PRP may be accounted as a hoping option for the treatment of rotator cuff injury, and preclinical and clinical evidence to date have demonstrate that PRP is safe. However, verified results of its efficiency has been combined and highly variable depending on the specific parameters, such as patient age, number and timing PRP injection, the different protocols and materials used in
Randomized Clinical Trials (RCTs) to produce and processing the PRP. More high-quality huge clinical trials will be necessary in providing our understanding of this treatment strategy in near future.

Due to repairing ability of MSCs, especially AD-MSCs and BM-MSCs, in musculoskeletal regenerative medicine, they could be used as one of most important cell source for disease treatment. MSC-Based therapy could help propel progress to a rotator cuff injury, especially now that great progress is being made in isolating and differentiating adipose-derived and bone marrow-derived mesenchymal stem cells. Although pre-clinical and clinical studies have provided promising results for the use of these cells in the disease treatment, however, larger and higher-quality studies are needed to gain a more accurate understanding of the therapeutic mechanism and efficacy of this strategy in future.

Taken together, the preclinical studies' results strongly suggested that PRP and MSCs may play a curative role in rotator cuff injuries, however, further clinical studies are needed to reach greater potential for therapeutic application.

\section{Ethical Considerations}

\section{Compliance with ethical guidelines}

All ethical principles were considered in this article.

\section{Funding}

This research did not receive any specific grant from funding agencies in the public, commercial, or not-forprofit sectors.

\section{Authors contribution's}

Review, draft-writing: Mohsen Sheykhhasan; Review \& editing: Hamed Manoochehri, Pouria Samadi, Reza FotouhiArdakani; Supervision: Naser Kalhor.

\section{Conflict of interest}

The authors have no conflicts of interest to declare.

\section{Acknowledgements}

We express my deepest gratitude to Mrs. Farzaneh Chitsaz for her help in figure preparation. 


\section{References}

[1] Campi F, Garofalo R, Castagna A. Irreparable rotator cuff tears. In: Gumina S, Grassi F, Paladini P, editors. Reverse Shoulder Arthroplasty. New York: Springer, Cham; 2019. [DOI:10.1007/978-3-319-97743-0_13]

[2] Akyol E, Hindocha S, S Khan W. Use of stem cells and growth factors in rotator cuff tendon repair. Curr Stem Cell Res Ther. 2015; 10(1):5-10. [DOI:10.2174/157488 8X09666140710101001] [PMID]

[3] Lin KM, Wang D, Dines JS. Injection therapies for rotator cuff disease. Orthoped Clin. 2018; 49(2):231-9. [DOI:10.1016/j. ocl.2017.11.010] [PMID]

[4] Beaudreuil J, Dhenain M, Coudane H, Mlika-Cabanne N. Clinical practice guidelines for the surgical management of rotator cuff tears in adults. Orthopaed Traumatol: Surg Res. 2010; 96(2):175-9. [DOI:10.1016/j.otsr.2010.02.002] [PMID]

[5] Parada SA, Dilisio MF, Kennedy CD. Management of complications after rotator cuff surgery. Curr Rev Musculoskeletal Med. 2015; 8(1):40-52. [DOI:10.1007/s12178-014-9247-6] [PMID] [PMCID]

[6] Khair MM, Gulotta LV. Treatment of irreparable rotator cuff tears. Curr Rev Musculoskeletal Med. 2011; 4(4):208-13. [DOI:10.1007/s12178-011-9098-3] [PMID] [PMCID]

[7] Rothrauff BB, Pirosa A, Lin H, Sohn J, Langhans MT, Tuan RS. Stem cell therapy for musculoskeletal diseases. Amsterdam: Elsevier; 2019. [DOI:10.1016/B978-0-12-809880-6.00054-0]

[8] Patel S, Gualtieri AP, Lu HH, Levine WN. Advances in biologic augmentation for rotator cuff repair. Ann N Y Acad Sci. 2016; 1383(1):97-114. [DOI:10.1111/nyas.13267] [PMID] [PMCID]

[9] Giuseppe Longo U, Rizzello G, Berton A, Maltese L, Fumo C, Khan W, et al. Biological strategies to enhance rotator cuff healing. Cur Stem Cell Res Ther. 2013; 8(6):464-70. [DOI:10.2174/15 74888X113086660065] [PMID]

[10] Prabhath A, Vernekar VN, Sanchez E, Laurencin CT. Growth factor delivery strategies for rotator cuff repair and regeneration. Int J pharmaceut. 2018; 544(2):358-71. [DOI:10.1016/j.ijpharm.2018.01.006] [PMID]

[11] Noh KC, Park SH, Yang CJ, Lee GW, Kim MK, Kang YH. Involvement of synovial matrix degradation and angiogenesis in oxidative stress-exposed degenerative rotator cuff tears with osteoarthritis. J Shoulder Elbow Surg. 2018; 27(1):141-50. [DOI:10.1016/j.jse.2017.08.007] [PMID]

[12] Samadi P, Sheykhhasan M, Khoshinani HM. The use of platelet-rich plasma in aesthetic and regenerative medicine: A comprehensive review. Aesthetic Plast Surg. 2019; 43(3):1-12. [DOI:10.1007/s00266-018-1293-9] [PMID]

[13] Sheykhhasan M, Mohammadi S, Nikbakht M, Ghiasi M. The use of platelet-rich plasma in intervertebral disc regeneration: A review of preclinical studies and clinical experiments. Razi J Med Sci. 2017; 24(156):72-92.

[14] Dolkart O, Chechik O, Zarfati Y, Brosh T, Alhajajra F, Maman E. A single dose of platelet-rich plasma improves the organization and strength of a surgically repaired rotator cuff tendon in rats. Arch Orthop Trauma Surg. 2014; 134(9):1271-7. [DOI:10.1007/ s00402-014-2026-4] [PMID]
[15] Khairy Y, Nasr M, Ali F, Ali R, Abdelhakeem M, Khalil A THU0495 role of platelet rich plasma in treatment of rotator cuff tendinopathy and partial thickness tear: Follow up by ultrasound. Ann Rheum Dis. 2019; 78:537-8. [DOI:10.1136/annrheumdis-2019-eular.4218]

[16] Dukan R, Bommier A, Rousseau MA, Boyer P. Arthroscopic knotless tape bridging with autologous platelet-rich fibrin gel augmentation: Functional and structural results. Phys SportsMed. 2019; 47(4):455-62. [DOI:10.1080/00913847.2019 .1623994] [PMID]

[17] Martinelli D, Fornara P, Stecco A, Grassi FA. Does intraoperative platelet-rich plasma improve clinical and structural outcomes after arthroscopic repair of isolated tears of the supraspinatus tendon? Indi J Orthop. 2019; 53(1):77-81. [DOI:10.4103/ ortho.IJOrtho_35_17] [PMID] [PMCID]

[18] Schwitzguebel AJ, Kolo FC, Tirefort J, Kourhani A, Nowak A, Gremeaux V, et al. Efficacy of platelet-rich plasma for the treatment of interstitial supraspinatus lesions: A randomized, double-blinded, controlled trial: PRP for Interstitial Supraspinatus Lesions. Orthop J Sport Med. 2019; 7(5_suppl. 3):2325967119S00210. [DOI:10.1177/2325967119S00210] [PMCID]

[19] Wang C, Xu M, Guo W, Wang Y, Zhao S, Zhong L. Clinical efficacy and safety of platelet-rich plasma in arthroscopic full-thickness rotator cuff repair: A meta-analysis. PloS One 2019; 14(7):e0220392. [DOI:10.1371/journal.pone.0220392] [PMID] [PMCID]

[20] Greenspoon JA, Moulton SG, Millett PJ, Petri M. The role of Platelet Rich Plasma (PRP) and other biologics for rotator cuff repair. The Open Orthop J. 2016; 10:309-14. [DOI:10.2174/18743 25001610010309] [PMID] [PMCID]

[21] Middleton KK, Barro V, Muller B, Terada S, Fu FH. Evaluation of the effects of Platelet-Rich Plasma (PRP) therapy involved in the healing of sports-related soft tissue injuries. The Iowa Orthop J. 2012; 32:150-63.

[22] Warth RJ, Dornan GJ, James EW, Horan MP, Millett PJ. Clinical and structural outcomes after arthroscopic repair of fullthickness rotator cuff tears with and without platelet-rich product supplementation: A meta-analysis and meta-regression. Arthroscopy: J Arthroscop Relat Surg. 2015; 31(2):306-20. [DOI:10.1016/j.arthro.2014.09.007] [PMID]

[23] Shams A, El-Sayed M, Gamal O, Ewes W. Subacromial injection of autologous platelet-rich plasma versus corticosteroid for the treatment of symptomatic partial rotator cuff tears. Eur J Orthop Surg Traumatol. 2016; 26(8):837-42. [DOI:10.1007/s00590016-1826-3] [PMID]

[24] Charles MD, Christian DR, Cole BJ. The role of biologic therapy in rotator cuff tears and repairs. Curr Rev Musculoskelet Med. 2018; 11(1):150-61. [DOI:10.1007/s12178-0189469-0] [PMID] [PMCID]

[25] Castricini R, Longo UG, De Benedetto M, Panfoli N, Pirani P, Zini R, et al. Platelet-rich plasma augmentation for arthroscopic rotator cuff repair: A randomized controlled trial. Am J sports Med. 2011; 39(2):258-65. [DOI:10.1177/0363546510390780] [PMID]

[26] Randelli P, Arrigoni P, Ragone V, Aliprandi A, Cabitza P. Platelet rich plasma in arthroscopic rotator cuff repair: A prospective RCT study, 2-year follow-up. J Shoulder Elbow Surg. 2011; 20(4):518-28. [DOI:10.1016/i.jse.2011.02.008] [PMID] 
[27] Randelli PS, Arrigoni P, Cabitza P, Volpi P, Maffulli N. Autologous platelet rich plasma for arthroscopic rotator cuff repair. A pilot study. Disabil Rehab. 2008; 30(20-22):1584-9. [DOI:10.1080/09638280801906081] [PMID]

[28] Kesikburun S, Tan AK, Yılmaz B, Yaşar E, Yazıcıŏlu K Platelet-rich plasma injections in the treatment of chronic rotator cuff tendinopathy: A randomized controlled trial with 1-year follow-up. Am J sports Med. 2013; 41(11):2609-16. [DOI:10.1177/0363546513496542] [PMID]

[29] Rha Dw, Park GY, Kim YK, Kim MT, Lee SC. Comparison of the therapeutic effects of ultrasound-guided platelet-rich plasma injection and dry needling in rotator cuff disease: A randomized controlled trial. Clinical Rehab. 2013; 27(2):113-22. [DOI:10.1177/0269215512448388] [PMID]

[30] Jo CH, Kim JE, Yoon KS, Lee JH, Kang SB, Lee JH, et al. Does platelet-rich plasma accelerate recovery after rotator cuff repair? A prospective cohort study. Am J sports Med. 2011;39(10):208290. [DOI:10.1177/0363546511413454] [PMID]

[31] Jo CH, Shin JS, Lee YG, Shin WH, Kim H, Lee SY, et al. Platelet-rich plasma for arthroscopic repair of large to massive rotator cuff tears: A randomized, single-blind, parallel-group trial. Am J sports Med. 2013; 41(10):2240-8. [DOI:10.1177/0363546513497925] [PMID]

[32] Jo CH, Shin JS, Shin WH, Lee SY, Yoon KS, Shin S. Platelet-rich plasma for arthroscopic repair of medium to large rotator cuff tears: A randomized controlled trial. Am J sports Med. 2015; 43(9):2102-10. [DOI:10.1177/0363546515587081] [PMID]

[33] Lee HW, Choi KH, Kim JY, Yang I, Noh KC. Prospective clinical research of the efficacy of Platelet-rich plasma in the outpatient-based treatment of rotator cuff tendinopathy. Clin Shoulder Elbow. 2019; 22(2):61-9.

[34] Ibrahim DH, El-GazzarNM, El-Saadany HM, El-Khouly RM. Ultrasound-guided injection of platelet rich plasma versus corticosteroid for treatment of rotator cuff tendinopathy: Effect on shoulder pain, disability, range of motion and ultrasonographic findings. Egypt Rheumatol. 2019; 41(2):157-61. [DOI:10.1016/j. ejr.2018.06.004]

[35] Carr AJ, Murphy R, Dakin SG, Rombach I, Wheway K, Watkins B, et al. Platelet-rich plasma injection with arthroscopic acromioplasty for chronic rotator cuff tendinopathy: A randomized controlled trial. Am J Sports Med. 2015; 43(12):2891-7. [DOI:10.1177/0363546515608485] [PMID]

[36] Mora MV, Ibán MAR, Heredia JD, Laakso RB, Cuéllar R, Arranz MG. Stem cell therapy in the management of shoulder rotator cuff disorders. World J Stem Cells. 2015; 7(4):691-9. [DOI:10.4252/wjsc.v7.i4.691] [PMID] [PMCID]

[37] Sheykhhasan M, Manoochehri H, Pourjafar M, Fayazi N Mesenchymal stem cells as a valuable agent in osteoarthritis treatment. Stem Cell Investig. 2018; 5:1-2. [DOI:10.21037/ sci.2018.11.04] [PMID] [PMCID]

[38] Narayanan G, Nair LS, Laurencin CT. Regenerative engineering of the rotator cuff of the shoulder. ACS Biomat Sci Engineer. 2018; 4(3):751-86. [DOI:10.1021/acsbiomaterials.7b00631]

[39] Ghiasi M, Kalhor N, Tabatabaei Qomi R, Sheykhhasan M. The effects of synthetic and natural scaffolds on viability and proliferation of adipose-derived stem cells. Fron Life Sci. 2016; 9(1):32-43. [DOI:10.1080/21553769.2015.1077477]
[40] Qomi RT, Sheykhhasan M. Adipose-derived stromal cell in regenerative medicine: A review. World J Stem Cells. 2017; 9(8):107-17. [DOI:10.4252/wjsc.v9.18.107] [PMID] [PMCID]

[41] Kim YS, Sung CH, Chung SH, Kwak SJ, Koh YG. Does an injection of adipose-derived mesenchymal stem cells loaded in fibrin glue influence rotator cuff repair outcomes? Clin magnetic Reson Imaging Stud. 2017; 45(9):2010-8. [DOI:10.1177/0363546517702863] [PMID]

[42] Ghiasi M, Tabatabaei Qomi R, Kalhor N, Fazaeli H, Mehdizadeh M, Sheykh hasan M. The design of scaffolds for use in tissue engineering. SMU Med J. 2014, 1(25):261-73.

[43] Kevin Wallevand Forum News Service. Stem cell treatment for rotator cuff injuries gets safety approval from FDA: Researchers in ND, SD lead project [Internet]. 2019 [Updated 2019 Jan 5]. Available from: https://www.aberdeennews.com/stemcell-treatment-for-rotator-cuff-injuries-gets-safety-approval/ article_6b545e17-9767-529e-8def-a700bbefce06.html.

[44] Cole BJ, Verma NN, Yanke AB, Bach BR, Otte RS, Chubinskaya $\mathrm{S}$, et al. Prospective randomized trial of biologic augmentation with mesenchymal stem cells in patientsundergoing arthroscopic rotator cuff repair. Orthop J Sports Med. 2019; 7(7 suppl. 5):1-2. [DOI:10.1177/2325967119S00275] [PMCID]

[45] Hernigou P, Lachaniette CHF, Delambre J, Zilber S, Duffiet $\mathrm{P}$, Chevallier N, et al. Biologic augmentation of rotator cuff repair with mesenchymal stem cells during arthroscopy improves healing and prevents further tears: A case-controlled study. Int Orthop. 2014; 38(9):1811-8. [DOI:10.1007/s00264014-2391-1] [PMID]

[46] Hernigou P, Merouse G, Duffiet P, Chevalier N, Rouard H. Reduced levels of mesenchymal stem cells at the tendonbone interface tuberosity in patients with symptomatic rotator cuff tear. Int orthop. 2015; 39(6):1219-25. [DOI:10.1007/ s00264-015-2724-8] [PMID]

[47] Havlas V, Kotaska J, Konicek P, Trc T, Konradova S, Koci Z, et al. [Use of cultured human autologous bone marrow stem cells in repair of a rotator cuff tear: preliminary results of a safety study (Czech)]. Acta Chir Orthop Traumatol Cech. 2015; 82(3):229-34.

[48] Lee SY, Kim W, Lim C, Chung SG. Treatment of lateral epicondylosis by using allogeneic adipose-derived mesenchymal stem cells: A pilot study. Stem Cells. 2015; 33(10):2995-3005. [DOI:10.1002/stem.2110] [PMID]

[49] Connor DE, Paulus JA, Dabestani PJ, Thankam FK, Dilisio MF, Gross RM, et al. Therapeutic potential of exosomes in rotator cuff tendon healing. J Bone Miner Metab. 2019; 37(5):1-9. [DOI:10.1007/s00774-019-01013-z] [PMID]

[50] Wang C, Song W, Chen B, Liu X, He Y. Exosomes isolated from adipose-derived stem cells: A new cell-free approach to prevent the muscle degeneration associated with torn rotator cuffs. Am J of Sports Med. 2019; 47(13):3247-55. [DOI:10.1177/0363546519876323] [PMID]

[51] Shi Z, Wang Q, Jiang D. Extracellular vesicles from bone marrow-derived multipotent mesenchymal stromal cells regulate inflammation and enhance tendon healing. J Translat Med. 2019; 17(1):1-12. [DOI:10.1186/s12967-019-1960-x] [PMID] [PMCID] 
This Page Intentionally Left Blank 